\title{
EDUCATION FOR LIFE
}

\section{MICHAEL A. SIMPSON}

\section{OPSOMMING}

Opvoedkundige teorie en praktyk berus op teveel mites wat verwerp behoort te word.

Die ware beginsels van leer is dat alle mense 'n natuurlike gawe en potensiaal tot leer en 'n gretige nuuskierigheid oor die wêreld het. Leer sal meer geredelik plaasvind as die leerder voel dat die vak met sy behoeftes verband hou en as hy aktief in die leerproses betrokke is. Die waardevolste les is om te leer hóé om te leer.

Meeste eksamens toon misleidende resultate en teveel van die kurrikuluminhoud bestaan gewoonlik uit nie-noodsaaklike kennis. Daar is ook 'n verborge kurrikulum waaruit die student onjuiste feite leer.

Die beginsels van ware opvoeding word geintegreer in Probleem-Gerigte Onderrig waarin studente met werklike probleme gekonfronteer word en self die inligting wat hulle nodig het om die probleem op te los moet gaan soek. Hierdie onderrigwyse is by McMaster Universiteit ontwikkel en met sukses in die kursus vir die Gevorderde Diploma in Moeder en Kindergesondheid vir verpleegkundiges in Natal toegepas.

\section{INTRODUCTION}

I'll do something rather dangerous today, and something very unusual for a major national expert in education. I'll tell the truth about education. It's not a pretty story, because it's a story of murder. Soul murder; the persistent diminution of the natural spirit of inquiry; the solemn clipping of wings; nurturing bonsai brains, preparing not for growth and creation throughout life, but sedation for the long littleness of life. John Kenneth Galbrath once said: If you can't always comfort the afflicted - sometimes its useful to afflict the comfortable.

\section{MYTHS ABOUT EDUCATION}

There are a great many myths, a regular fanfare of false beliefs, that underline too much of educational theory and practice. They need to be weeded out and discarded. These are not ideas to be lightly tossed aside - they should be thrown with great force. Let me summarise some of these universal untruths (and please bear in mind that everything said in the next paragraphs is wildly untrue).

You can't trust the student to learn - they'll never do it unless you force them to, or threaten them. The capacity to pass exams is the best criterion for selecting students and judging their promise. A regular percentage of students will

Prof. M.A. Simpson, MBBS; MRCS; LRCP: MRCPsych, DPM. Professor of Medical Education, Department of Continuing Medical Education, University of Natal. fail any exam - if there aren't enough failures, this reveals a bad teacher, who's too soft. You raise the standards of education by maintaining high and regular failure rates. What you teach is what they learn; all they learn is what you teach. Knowledge is a solid wall, built up brick by brick out of solid fact.

Passive learning works best. Learners should sit still, shut up. listen to what the teacher says -and then repeat it during the exam (that's a fine way to train tape-recorders, not children, doctors or nurses). Discovering knowledge is beyond the power of students, and in any case is none of their business.

Recall of facts is the highest form of intellectual achievement. One's own ideas, and those of class-mates, are unimportant, for Feelings are irrelevant in education. All students know nothing (or they wouldn't be students); all teachers know all the answers (or they wouldn't be teachers); all questions have one right answer. Students should be dependent on teachers.

What we're doing already is of course very good indeed, and we need no proof or evidence for that Any new idea or technique, though, must be rejected or resisted until there is overwhelming and irresistable proof that it works perfectly in every case.

Should anyone dare to provide some proof that it works perfectly in every case. Should anyone dare to provide some proof we can still avoid change in several ways we'll explain that it's too expensive, or that there's no time in the curriculum, or that its already taught (even if rather subtly and invisibly) throughout the curriculum, so there's really no need to change. Finally there's the belief that change is an option, that we can choose not to change. Educators are so often like the baby being weaned, who, had he the power of speech, would look up indignantly from the breast and say How dare you ask me to change the habits of a life-time!

\section{NOW THE TRUTH}

I shall now resume telling the truth. I'm a dreadfully unskilled liar, and can never keep it up for long. What are the true principles of learning and life? Almost exactly the reverse of those myths just listed. Quite simply these - all human beings have a natural gift and potential for learning, a blessedly greedy curiousity about the world. It is, all too often, blunted by their schooling. Learning is most likely when the student sees the subject as relevant to his own needs. Learning is best done by active participation, by doing, by being inspired or irritated, by growing the most vital and valuable learning of all is learning to learn, and to learn well. Education is, as the origins of the word reveal, about e-ducere - about leading out, about encouraging a continuing openness to experience. Sadly, what most students mostly do in class is guess what the teacher wants them to say. 


\section{Learning}

Unless you train them to be taught, rather than to learn, students are eager to learn, without coercion; indeed its hard to stop them. Watch a child playing in the back-yard, in an orgy of perception - picking up things, pushing them, dropping them, smelling them, tasting them. He protests and struggles if you try to stop him. No one told him to learn, or how to. The speed with which infants learn the infinitely complex skills of walking and talking is incredibly fast and accurate, and it is accomplished without a teacher though in active dialogue with the world. In this, perhaps, because there's no teacher and he's not yet at school?

Sometimes I am asked to see a teenager because he's doing badly at school, and they tell me that he can't learn - year I find he's mad about motor-bikes or pop music or growing vegetables. And he has worked extremely hard and learned a great deal about these subjects although they're not in the curriculum and not examined. Or is it because they're not in the curriculum or examined? There seems to be a sort of Vaccination Theory of Education which holds that a subject is something you take; and when you've taken it, you've had it, and you're immune, and don't need to take it again.

\section{Examinations}

Most examinations produce artificial and misleading results, which don $t$ predict anything interesting or useful in the future. At best they predict, rather badly, how well the student might perform in the near future in an exam very similar to the one they've just taken. So what? Is taking exams the career for which we're preparing them?

Most teachers are so hung up about teaching that they overlook the central fact that the only thing that matters is learning. Teachers are eager to take credit for their students' success, while making it quite clear that failure is entirely the responsibility of the student. Its like when you get back home following an afternoon away and your spouse meets you at the door. If the opening words are: Do you know what your children did?, you know they have been naughty. If they have done something lovely, they'll be called our children. For a teacher to say Oh I taught them all about it but they didn't learn, is just like a salesman saying $O h$ I sold him the car - but he didn't buy it. If they didn't learn, you didn't teach.

The artificial creation of a normal curve in examination results often leads to the mischievous belief that a certain proportion ought to fail, and that a teacher has erred if too many students pass. Why is education so heavily invested in failure? Why is it that so many teachers never award $100 \%$ or $90 \%$, however good the work? If you tell students what you want them to learn, and help them learn it, and assess exactly the right thing, you should get 95 to $100 \%$ success. If you don't, there is something awfully wrong.

Evaluation should be part of learning, not something set aside from it. Too many terminal examinations are just that, for something dies every time. Examinations are usually like a postmortem - they occur too late to be of any use to the person assessed. They should be diagnostic and helpful, never punitive. Surely community nurses, more than anyone, know how much more important it is to prevent problems rather than to wail about the occurrence of preventable problems.

\section{Curriculum}

People are always full of ideas about what should be put in to the curriculum, but are very rarely explicit about what should be taken out of it. As a result, all curricula are a sort of intellectual doggy bag, chock full of stale left-overs. It is a useful, though rare, exercise to scrutinise your curriculum and to decide whether each and every part of it is essential and really needed for your students to be successful in life. Most of its content can be put into three piles - essential to know; quite nice to know (I don't mind if they know it, but wouldn't insist on it); and unnecessary to know. And we must have the courage to throw away that last pile, to make the middle pile voluntary, and thus allow ourselves and our students to concentrate on the modest pile of what is essential to know.

We overlook the fact that most subjects we teach are a sort of timeand-space-occupying lesion, like a brain tumour expanding within a small and finite space, producing pressure atrophy and compromising vital functions. By concentrating on the essentials, we not only ensure that they are properly learned, but leave room for them to be surrounded protectively by generous amounts of the nice-to-know stuff. When, in contrast, we try to push the whole overloaded doggy bag curriculum into the students, what they actually absorb is a small and random selection of the essential and the irrelevant.

A good example of the problem can be seen in contrasting two main approaches to evaluation - normreferenced and criterion-referenced.

Norm-referenced evaluation is what we normally use. The students' results are compared with each other, they are put in rank order. In various ways the fraction who are at the top of the class get A's - even if none of them have done particularly well; and if the whole class has done very well, the fraction at the bottom of the class will be failed, even if they've done well. It's quite possible in different years for students whose performance in one class would have gained them an A, to be failed in another class.

In contrast, in criterion-based evaluation you draw up criteria describing what the student needs to be able to do. If she can do it to the standards described she has passed. If she cannot, she must continue learning until she can do it well enough.

Let me show you a clear example of this in action. Suppose you want to teach a student how to make a cup of instant coffee. You can analyse the task and divide it into necessary steps - 1) Get the cup, 2) Get the saucer 3) Put the cup on the saucer 4) Get the coffee 5) Boil the water 6) Put coffee in cup 7) Add hot water 8) Get the milk 9) Add the milk 10) Stir. Then you mark the student's performance. 
One girl does everything right with one exception. She leaves out item (6) - she puts no coffee in the cup. Under a criterion-based system she fails and has to repeat it - she hasn't met the criterion of carrying out all ten stages and producing a cup of hot coffee. Under the usual norm-referenced system. she has only omitted one of the ten components. She'll score $90 \%$ and be near the top of your class - yet all she can produce is a cup of warm watery milk! Failing to use explicit criteria we are responsible for far too many graduates who produce only warm, watery milk.

We must help people to develop the habit of life-long learning. It is very sad that almost all Departments of Education or Pedagogy, and almost all textbooks on education seem to assume that learning ends, totally and irrevocably, in the mid-teenage years. Those of us concerned with true adult and tertiary education are, sadly, rare birds. Life and learning should, and can, continue through death.

\section{THE HIDDEN CURRICULUM}

Let me return for a while to the problems of what we do actually teach all too often. Normal schooling is a socially accepted way of keeping the kids off the streets and out of the job market. It has an ostensible curriculum - the one we show to visitors and reprint in the prospectus. It also has a hidden curriculum very effectively taught, even if very rarely spoken aloud or even recognised.

The Hidden Curriculum teaches many things which could be listed as follows (and remember, these statements too, are untrue):

Facts are good. Swallow and store as many of them as possible. It doesn't matter if you dont know what to do with them. Facts are like stamps - to be saved in an album. rather than used to send a letter and reach someone else.

Disagreement is bad; questioning is wrong. Obedience is good. The teacher knows. Agree. Accept without question. (On the contrary, of course, the good teacher gives the precious gift of good questions, not the tawdry donation of tatty, second-hand answers).

Sex is bad. Sex is a filthy, horrible thing - which you must save for the person you love. (So, students don't learn how to understand and responsibly enjoy their own sexuality. At best they learn the bare facts of biology, but nothing about love).

Fun is bad. Education must be solemn and unpleasant. If you're enjoying it, you can't be learning. Conversely, if you're not enjoying it, it must be educational and good for you - like medicine, it must taste bad to do good.

Making money is good, the more the better (look at the vulgar wallet worship on Prime Time television). Spending money is better, and the more stuff you've bought, the better you are. People with little or no money, and less stuff, hardly count.

You can't learn by yourself you need a teacher. You don't know how good you are - you need an examiner to tell you. Failure is inevitable - and the good teacher has high failure rates. Raising failure rates is raising standards. (To me, this is like saying you'll raise the standards of health in KwaZulu by raising the level of the normal Haemoglobin to $57 \mathrm{mg} \mathrm{\% )}$ ).

Truth doesn't matter (and besides, it's often incomfortable). Don't look for it. If you should stumble over it, pick yourself up quickly, dust off, and hope no-one will notice. Meaning is unimportant.

Yet, as my friend Viktor Frankl learned in the concentration camps Everything can be taken from a man but one thing: the last of the human freedoms - to choose one's own attitude in any given set of circumstances; to choose one's own way.

\section{PROBLEM-BASED LEARNING}

So, what should we do about it? We can embody the principles of real education in a system suitable for all levels from junior school through university to graduate training. We call it Problem-Based Learning. Let me explain its basic elements.

Suppose we are sending a young man on a long journey through wild territory, how should he prepare for it? The traditional curriculum does this: it piles his little boat with all the food he might need for years even if some of it will be rotten before he needs it, or so heavy that it threatens to overturn his boat. And it adds everything else he might possibly need - a formal dress suit and bow-tie in case he's invited to an unexpected wedding; a tennis racket in case he finds an abandoned tennis court and a partner, and so on. On the other hand, wouldn't it be better to teach him the skills of managing a boat, hunting, cooking, and shelter-building - so that he can find, get and make what he needs, if and when he needs it? Analogously, in Education, the essential skill to teach is problem solving.

This system, which we developed in Canada at McMaster University, and which has been used as the basis of new schools in Holland, Israel and Australia, is natural and effective. We have been using it here in Natal in our Higher Diploma in Maternal and Child Health course for nurses from Natal and KwaZulu, with splendid results. It is perfectly suited to our community needs and uses fully the knowledge and experiences of our learners.

\section{The method}

Basically, this method means that we don't give series of lectures, expecting students to remember a vast number of things in the hope that later on, if they ever meet a real problem that needs that data, they'll manage to remember them and will work out what on earth to do with them. Instead, we turn that process upside down.

The student works in a small group of colleagues, and is given real clinical cases to consider. The group discusses the problem and its components and they decide what relevant knowledge they already have and what more they need to know to fully understand what the 
patient's problems are, how and why they arose, what consequences are likely, what one can do about it, how one could intervene, and what results one would expect.

Rather than having lectures on physiology and anatomy to try and find some later use for; they start with the real clinical problems and discover what anatomy, psychology, and so forth, they need. The students divide up the work needing to be done. They go off and use a range of resources, libraries, experts, and information from their own community. They gather the information needed, bring it back, and share it in the group, where they collaborate so as to fully comprehend and explain the nature of the problem and its management.

Facts are learned in the way they're learned best. Not as isolated bits of knowledge, but as a network of knowledge where each fact was needed in a real clinical context, discovered (meanwhile learning where to get good data) and used.

The students are given general course objectives by the planners, as guidelines to help them decide how to use each problem. But they must also set further, detailed, personal objectives themselves. Based on their particular characteristics and background, students have unique needs. In discussion with their colleagues and tutor they set specific personal objectives.

The evaluation within such a course depends on these objectives. There are no exams. That is, there are no times when everyone sits down and takes the same test. But each student uses a range of testing materials for her own information and is her own primary examiner. The student reveals her evaluation within the group - telling the group how well she thinks she's achieved what she set out to do what she's learned well, what objectives she's met, what she still needs to learn, and where she has problems. Her colleagues discuss this, adding their own peer assessments and considering the evidence the student offers for her own assessment. The tutor then adds his views, validates the consensus evaluation, and records it.

Table 1 GOALS OF THE PROGRAMME AT McMASTER UNIVERSITY

The graduates will have acquired or developed the knowledge, abilities and attitudes necessary to qualify for further education in any health career. The general goals of the programme are that the graduate will be able:

1) to identify and define health problems, and search for information to resolve or manage these problems;

2) given a health problem, to examine the underlying physical or behavioural mechanisms. A spectrum of phenomena may be included, from molecular events to those involving the patient's family and community;

3) to recognize, maintain, and develop personal characteristics and attitudes required for professional life, including: awareness of personal assets, potential, limitations and emotional reactions, responsibility and dependability, and the ability to relate to and show concern for other individuals;

4) to develop the clinical skills and methods required to define and manage the health problems of patients, including their physical, emotional and social aspects;

5) to become a self-directed learner, recognizing personal educational needs, selecting appropriate learning resources, and evaluating progress;

6) to be able to critically assess professional activity related to patient care, health care delivery, and medical research;

7) to be able to function as a productive member of a small group, whether engaged in learning, research or health care;

8) to be aware of and be able to work in a variety of health care settings.

In Canada we have used the same methods, even with alienated highschool dropouts, to study a broad range of subjects, and with substancial success.

It's absolutely impossible to train anybody in any field, at any one time, so as to enable them to remain competent for life — unless we accept as a central aim of all our educational programmes the initiation and encouragement of the central, essential skill of life-long learning, the skills of learning to learn. These methods place considerable responsibility on the student - and they meet the responsibilities. Treat students as irresponsible, incompetent and lazy, and they'll meet your expectations. Treat them as competent, concerned, active adult learners and they can meet that expectation as well.

Rather than the vast collections of detailed behavioral objectives some schools can show you, McMaster summed up what it wanted to achieve in basic, clear points. The objectives of the programme are given in table 1 .

\section{CONCLUSION}

The role of the true teacher was well described a very long time ago by Socrates, who explained: My art is like that of midwives but differs from theirs in that I. . look after their minds when they are in labor and not after their bodies; and the triumph of my art is in thoroughly examining whether the thought which the mind of the young man brings forth is a phantom and a lie, or a fruitful and true birth . . the reproach often made against me, that I ask questions of others and have not the wit to answer them myself, is very just ... but those with my profit. ... They make astonishing progress. It is quite clear that they never learned anything from me; all that they master and discover comes from themselves. But to me and to the gods, they owe their delivery.

It is to the practice of this sort of intellectual obstetrics that we should be devoted, in any kind of educational system - increasing mental fertility, nurturing the growth of Mind, and facilitating learning and the birth of new ideas.

The realities of teaching and learning in the way I've described are exhilarating. But some of you may have found these suggestions alarming, disturbing proposals for change. In closing, let me remind you of John Gardner's relevant comments. He said: 
I am always puzzled by people who talk as though the advocates of change (were) just inventing ways to disturb the peace in what would otherwise by a tranquil community. We are not seeking change for the sheer fun of it. We must change to meet the challenge of altered circumstances. Change will occur whether we like it or not. It will be either change in a good and healthy direction or change in a bad and regrettable direction. There is no tranquillity for us.
We can choose not to accept the challenge, of course, but then we shall fall very rapidly into the ranks of the museum nations, and tourists from more vigorous lands will come from afar to marvel at our quaint ways.

Let us be vigorous rather than quaint!

To discover what is needed in terms of educational growth and development look to the community and what they need. Nurses know well how different things look and are in the dorps and villages from the way things are expected to be in the marble halls of senior planners and administrators. Ask the community, ask the people - don't just ask the folks in charge, at the top.

If you want to make an omelette, don't ask the Hen for advice. She may know a lot about eggs, but her motivation is very different from yours.

\section{SUMMARY AND CONCLUSIONS}

Unsupported adolescent pregnancy carries a high risk of adverse consequences, both short term and long term, for mother, child and family. These consequences result from an interaction between a number of biological and socio-economic factors, many of which are amenable to intervention. Of greatest concern are:

- the increased frequency of low infant birthweight and its associated risks of mortality and neurological and/or intellectual impairment

- early repeat pregnancy

- inadequate parenting, with its limiting effect on the physical, social and emotional development of the child, leading in many instances to the repetition of the adolescent pregnancy cycle.

These problems can have enormous costs in human and financial terms.

The health professional can contribute to alleviating the problems associated with teenage pregnancy by two types of intervention, namely, to provide adolescents with meaningful and acceptable birth control and to provide the supportive services during and following pregnancy which will maximise the health and development of the mother and child.
The supportive service/progranime should include the following objectives:

- to assist in the primary prevention of adolescent pregnancy

- to prevent school drop-out with its subsequent limitations on employment

- to optimise adolescent and infant health and development so that a stable and self-sustaining family unit results

- to prevent the recurrence of pregnancy until a more favourable age

- to prevent child neglect and abuse

- to foster linkages amongst community organisations to meet adolescent needs efficiently

- to provide training of personnel and consultation to other organisations

- to evaluate the effectiveness and cost effectiveness of the service/programme

- to serve as a research base for the study of problems relating to adolescent child bearing and parenting.

A multidisciplinary service/programme providing comprehensive medical, psycho-social and health educational services is essential to meet the stated objectives. must want not to become pregnant, and both females and males must want not to become parents during their adolescent years. A broader approach to the issue of prevention is required to accomplish this objective. It should involve improvements in the life situations of young people and a belief, based on facts, that attainable goals in life would be thwarted by early parenthood.

For many adolescent girls motherhood is still the easiest and fastest way of becoming an adult woman and for many adolescent boys making it, with or without fatherhood, is the clearest proof of adult masculinity. Only as alternative routes of adulthood become available, through increased opportunities for education and employment for both teenage girls and boys, will the ideals regarding preventing pregnancy, as well as regarding childbirth and childrearing be achieved.

\section{REFERENCES}

Brown. W.A. (1980) Psychological care during pregnancy and the post partum period New York. Raven Press. Campbell, A. (1968) The role of family planning and the reduction of poverty Journal of Marriage and the Family. Vol. 30: $236-237$

Hollingsworth, D. R.; Ericson, A J. : Dought, G.H. (1978) Drugs and adolescent pregnancy. Adolesent obstetrics and gynaecology. Chicago. Year Book Medical Publishers. 2nd Ed.

McKay. J. (1984) The health risks of teenage sex. People. Vol. 12. No. 1: 8-9.

Olds. S. B.: London, M L.: Ladewig. P. A. (1980) Maternalnewborn nursing. A family-centred approach California Addison-Wesley. 2nd Ed.

Scott. K.G.: Field, T.; Robertson, E. (1981) Teenage parents and their offspring New York. Grune and Stratton. Tyrrell. D.M. (1984) Schoolgirl mothers Nursing Times. Vol. 80, No. 21: 29-31

Webb. G. A.; Briggs. C.: Brown. R.C. (1972) A Compre hensive adolescent maternity programme in a communit hospital American Journal of Obstetrics and Gynecology. Vol. 113: 511 . 